DOI: https://doi.org/10.47405/mjssh.v6i10.1084

\begin{tabular}{|c|c|}
\hline 4 & Malaysian Journal of Social Sciences and Humanities (MJSSH) \\
\hline $\begin{array}{l}\text { Malaysian Juoural of } \\
\text { Social ccciecces and }\end{array}$ & Volume 6, Issue 10, October 2021 \\
\hline (MJ-sSH) & e-ISSN : 2504-8562 \\
\hline & $\begin{array}{l}\text { Journal home page: } \\
\text { www.msocialsciences.com }\end{array}$ \\
\hline
\end{tabular}

\title{
Is The Covid-19 Vaccine Halal? Revisiting The Role of National Pharmaceutical Regulatory Agency (NPRA) and JAKIM
}

\author{
Norazlina Abdul Aziz", Siti Sarah Sulaiman', Muhammad Azril Roslan', \\ Ku Mohd Amir Aizat Ku Yusof ${ }^{2}$ \\ 1Faculty of Law, Universiti Teknologi MARA, Selangor, Malaysia \\ 2Department of Law, Universiti Teknologi MARA, Sabah campus, Malaysia \\ Correspondence: Muhammad Azril Roslan (azril004@uitm.edu.my)
}

\begin{abstract}
The urge to be vaccinated has increased rapidly during the outbreak of the COVID-19 pandemic. Resorting vaccine products is seen as the only way to break the chain of COVID-19 spread and eventually stop the pandemic. To this dire need, many consumers face the dilemma to be vaccinated or to opt-out of the vaccination program when the safety issues of vaccine products are widely circulated. The Muslim consumers, particularly, experiences double worry on the issue of safety and halal status of the vaccine product. Due to the emergency call to have the vaccine in the market as soon as possible, the innovation and production were carried out in an expedited manner, and the necessity to have the vaccine be certified as halal was bypass. When the news on the vaccine product uses non-halal ingredients reaches the Muslim community in Malaysia, they were taken aback and demanded immediate answers from the authorities. Thus, in addressing this issue, this study intends to critically analyse the role of NPRA and JAKIM in ensuring the safety and halal status of a product with the aim of suggesting a review of the existing role. This article adopts a qualitative research methodology where interviews will be the supporting method to a library-based and doctrinal study.
\end{abstract}

Keywords: halal pharmaceutical, vaccination, Covid-19 pandemic, National Pharmaceutical Regulatory Agency, JAKIM

\section{Introduction}

The Global health crisis that had been declared as a pandemic by WHO in 2020 requires the transformation of norms for the world population (Jamaluddin, MA, 2021). It impacted norms of living, working, innovating, social communication, celebration, education, and many more. For the pharmaceutical company, the out of control spread of the COVID-19 virus that is now moving in its second year is a call for the need to innovate vaccines that can reduce the fatal infection effects, prevent infection and eventually put reduce the morbidity case. Rapid activities to innovate and produce COVID-19 vaccine has taken place within the pharmaceutical industry. It is within the urgency call for vaccine production that many ethical and legal issues arise. Safety issues have championed the rally. The majority of consumers that received information questioning the safety and effectiveness of the vaccine are in a dilemma in making the decision to opt-in or out of the vaccination program. For Muslim consumers, the concern has double up to worry on the safety and halal status of the vaccine. The Muslim population is estimated to be 1.9 billion globally (refer to Table 1) (World 
Population Review, 2021). In Malaysia, 61.3\% of the population is Muslim that forms the majority population.

Table 1: Mapping the Muslim Population

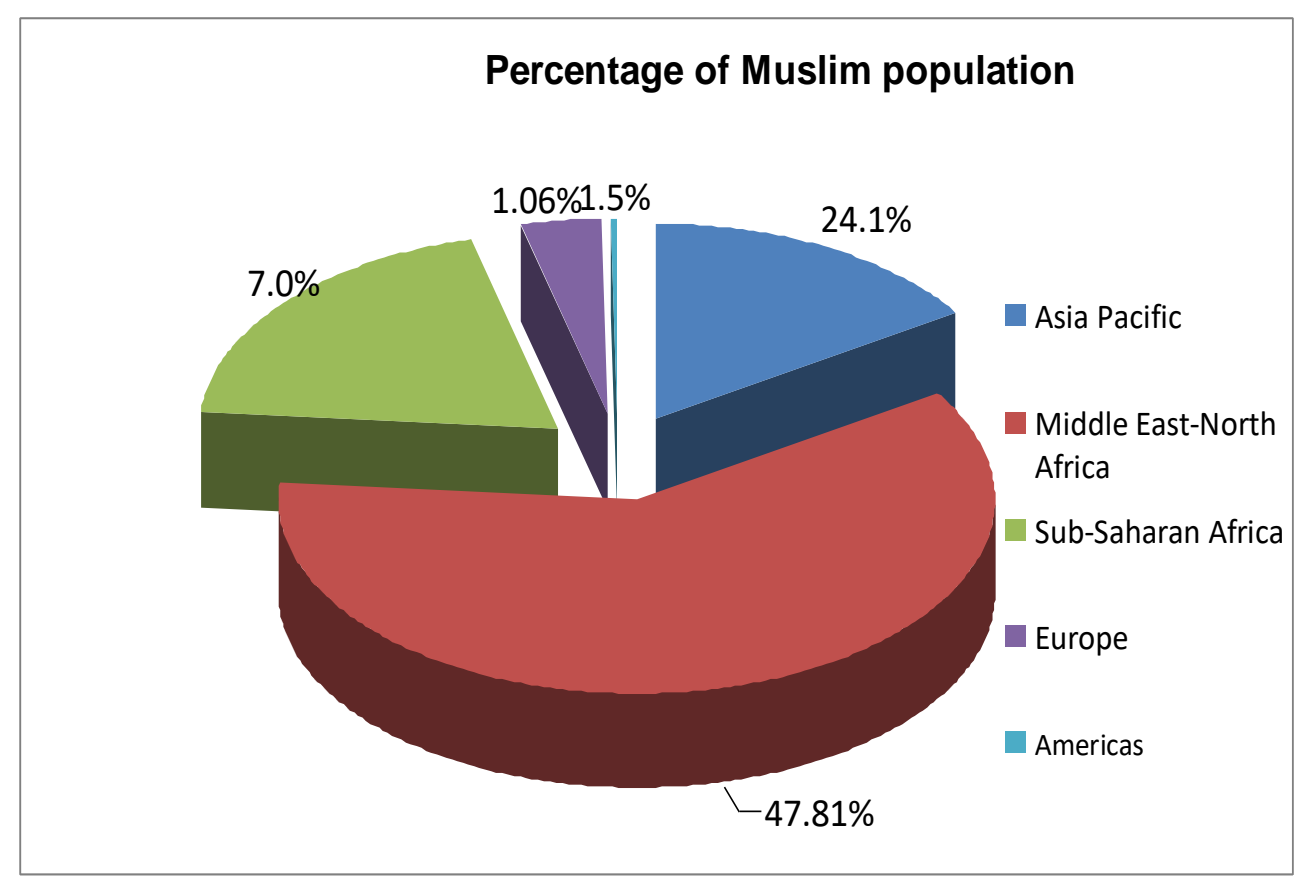

(Jeff Diamant, 2019)

The Global Halal market is valued at Million USD in 2018 and will reach Million USD by the end of 2025, growing at a CAGR during 2019-2025 (2 News, 2021). Significantly, Malaysia is recognised to have the potential in championing Halal pharmaceuticals manufacturing due to our membership to the Organization of Islamic Committee (OIC) and being the only OIC country accepted as a member under the Pharmaceutical Inspection Cooperation/Scheme (PIC/s). By being a member of Pharmaceutical Inspection Cooperation/Scheme (PIC/s), Malaysia has already owned its standing in the pharmaceutical industry globally. In responding to this opportunity, the government has a noteworthy pay focus on the developing halal pharmaceutical industry. This can be clearly evident when the pharmaceutical, cosmetic and personal care industry was named as one of the focus areas under Malaysia's Third Industrial Master Plan (IMP-3) (Leonard Ariff Shatar, 2011). This can be seen through Malaysia's Third Industrial Master Plan (IMP-3), where the pharmaceutical, cosmetic, and personal care industry was selected as one of the focused areas (Leonard Ariff Shatar, 2011).

With this existing recognition, having an appropriate legal framework on the halal vaccine would boost the Malaysian pharmaceutical product in the global market. NPRA is the main regulatory body for the pharmaceutical industry in Malaysia. However, there are several issues regarding its role in monitoring and developing halal pharmaceuticals in Malaysia. Thus, this article intends to review the existing role of NPRA and JAKIM in governing the safety, efficacy, quality, and halal status of the vaccine products with the aim of suggesting the revision of this role to ensure halal verification of the vaccine products.

It is a dilemma when numerous vaccine products begin to flood in this act of rescue, which has invited many manipulations and abuse of the existing laws. This relates to the fact that Muslims forms a large scale of the human population in the world, and their awareness of the need to consume halal products has escalated. The technology has increased the consumer's awareness and has resulted in the demand to know the actual contents of these products and the drug-making process which happens in the manufacturing premises. For Muslims, the halal verification and authentication of these products are highly required. For this reason, the Halal industry has become an important area in the market nowadays. 
In protecting the consumer, the halal pharmaceutical industry is basically administered by two authorities, namely, the National Pharmaceutical Regulatory Agency (NPRA) that is the Malaysian national Compliance Monitoring Authority appointed by the Ministry of Health to ensure the quality, efficacy, and safety of pharmaceuticals through licensing scheme. On the other hand, JAKIM governs the certification and monitoring of the halal aspect.

\section{Methodology}

This is socio-legal research to analyse and discuss the role of NPRA and JAKIM in assuring the safety and halal status of the COVID-19 vaccine. For that purpose, this research was designed based on the primary and secondary data as well as investigation of some social problems or questions which are essential in providing the solution to the issue. It is important to highlight that this paper did not focus on the empirical study as it aims at looking into the doctrinal and theoretical discussion which will best serve the suggestion put forward.

For the purpose of classification, the academic review will be conducted and subjected to content analysis, which is the most prominent method for qualitative research (Elo and Kyngäs, 2007; Lacyet al., 2015). The method involves accurate, comprehensive, and organised examination of important materials in selected paragraphs and sentences.

Primary data of this research have been obtained through interviews with the stakeholders in mediation and conciliation who are directly or indirectly involved in settlement of matrimonial disputes in Malaysia. They are the conciliators in the Department of Registration, mediators from the Malaysian Mediation Centre, Judges and Registrars of the High Court, academicians, and experts in this field. For comparative analysis, model law on family mediation from Singapore has been analysed. In addition to that, the secondary data were collected to provide better analysis and a comprehensive discussion of this research. For this purpose, a thorough examination will be conducted on halal related law, sales of drugs legal regime and related by-laws. Other secondary data includes relevant books, published articles and information from the internet.

\section{Finding and Discussions}

\section{Understanding Halal}

Through literature (Baran, 2020; Sue Penny, 2006; Mian N Riaz et al., 2003; Yusof Al Qardawi, 2009; Halal Journal, 2007), it can be summarised that the Halal concept is wide, and it applies to all facets of life. Under the Arabic word, the concept carries the meaning of lawful or permitted (Johan Fischer, 2005). Nevertheless, the common usage of these terms relates to food products, meat products, cosmetics, personal care products, food ingredients, and food contact materials (Mohd Cholil, 2020; Noreen Noor, 2015; Utusan Malaysia, 2003). Under the Shariah law, the products that we consume must be hygienic, pure, clean and of quality, or also known as 'Halalan toiyyibban' (Rokshana Sirin, 2018; Nik Maheran et al., 2009; Johan Fischer, 2008; Mian N. Riaz, 2004). The narrow understanding of the meaning 'halal' is it must be free from non-halal ingredients or substances that contain pork and alcohol (Mohd Cholil,2020). In contrast, the true concept of halal is to ensure that the whole process in preparation of the product has met the shariah rites. Halal promotes that not only what we consume must be Halal (follow the approved Shariah procedure), but the product must be 'toyyib' (wholesome).

To ascertain wholesome undertakes assurance along with the production of the products. Wholesome also anticipates issues of consumption of products that can promote and prolong once healthy life. The word Halal appears in many verses in the Al-Quran (2:172) and Al-Hadith

Based on the Arabic word, the concept carries the meaning of lawful or permitted (Mohd Cholil, 2020; Mian N Riaz et al., 2003). 
As far as foods are concerned, this term is always accompanied by the word thoyyiban. Hence, these denote foods that are permissible, good, pure, clean wholesome, fit etc. For example, Allah s.w.t says to the effect: -

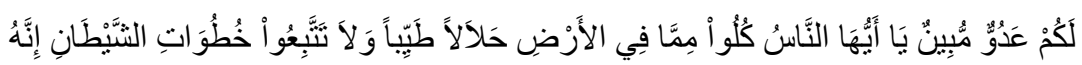

O ye people! Eat of what is on earth, Lawful and good; and do not follow the footsteps of the evil one, for he is to you an avowed enemy. (Al-Baqarah 2:168)

Nevertheless, in Islamic law, the term halal is not restricted to food consumption per se. The issue of halal encompasses a wide spectrum of human life in line with the goal of Shariah as a way of life. Hence, it also covers matters regarding finance, investment, fashion, entertainment and so on so forth (Baran, 2020, Mohd Cholil, 2020). For instance, in respect of financial matters, Allah s.w.t has clearly allowed buy and sale but strictly prohibited riba based on the following verse: -

$$
\text { الرِبَبَاوَحَرَّمَ الْبَيْعَ اللهُو وَأَحَلَّ.... }
$$

...but Allah hath permitted trade and forbidden usury. (Al-Baqarah 2:275)

In relation to the legal definition in Malaysia, few authors (Rosly Othman et al., 2007; Pazim Othman, 2009; Norazlina, 2017) have referred to the definition under the Trade Descriptions (Definition of Halal) Order, 2011. It can be said that this definition had narrowed the true conception of halal, anticipating the flaws of human-made law.

\section{Rules of Necessity under Islam}

Darurah in the Arabic language is derived from darar, which means an injury that cannot be avoided (Saim Kayadibi, 2010). Abdur Rashid extends the definition of darar to mean to harm, impair, damage, or hurt, which is the opposite of benefit (Mansour Z. Al-Mutairi, 1997). Thus, the Arabs call anyone who has lost his sight darir because of his obvious injury (Mansour Z. Al-Mutairi, 1997). Muslim jurists believed that the principle gains its legality from certain explicit textual evidence. Although these sources only deal with life and death situations, such as in the case of starvation, jurists further argued that this specific permission to eat other unlawful meals could be extended to other emergency cases (Yasmin Hanani, 2010).

Several writers (Abdul Rahman, 2021; Harmy Mohd Yusoff et al., 2011; Aznan Hasan, 2012; H.M Hasballah Thaib, 2004) who have researched and written on halal and haram acknowledged that necessity would lift the prohibition to use and consume haram goods, thus necessity permits prohibited things. However, it can be seen that the Islamic jurists are divided in agreeing on whether non-halal medicine is allowed to be taken in cases of necessity. Eminent Muslim scholars, like Yusuf al-Qaradawi states that some jurists do not consider non-halal medicine to be necessary for any emergency. He further states that these jurists cited the following Hadith to support their argument.

The Prophet Muhammad S.A.W. says,

"Allah has not made things that are unlawful for you to consume to be your medicine." (al-Bayhaqi)

On the other hand, other jurists maintain that in cases of emergency, the rule on non-halal is lifted (Jamaluddin, MA, 2021). They based their argument on the ground that both food and medicine preserve man's life. These jurists support their argument with the hadith of Prophet Muhammad S.A.W. narrated through Anas r.a.

They said that although male Muslims are not allowed to wear silk garments, the Prophet Muhammad S.A.W. has allowed both cAbdul al-Rahman ibn Awf and al-Zubayir ibn al-Awwam to wear it because of necessity. The two men were suffering from allergies (Shaykh Mufti Muhammad ibn Adam, 2002). 
Another authority on these matters can be found in the reports of Sayyidina Abu al-Darda' (Syekh ‘Abd Shukur Rahimy Mắmur Dawud, 2003) (Allah be pleased with him) quotes the wording of Prophet Muhammad S.A.W. that

"Indeed, Allah has sent down both illness and its cure, and he has assigned a cure for every illness, so treat yourselves medically, but use nothing unlawful." (Sahih al-Bukhari and Muslim)

Imam Abu Dawud, Imam Nasa'i and Imam Tirmidhi (Allah have mercy on them) referred to the Sunan collection that when one of the companions Arfaja ibn Aswad (Allah be pleased with him) had his nose damaged in the battle of Kulab, he replaced it first with silver, and then with a nose made of gold, with the order and consent of the Messenger of Allah s.w.t, despite gold being unlawful for men (Shaykh Mufti Muhammad ibn Adam, 2019).

All these jurists based their findings on the divine words of Allah (SWT) from the al-Qur'an. The following verse becomes the authorities for necessity:

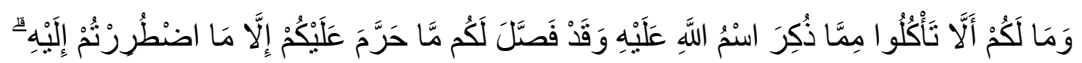

"Why should you not eat of (meats) on which Allah's name has explained to you in detail what is forbidden to you except under compulsion of necessity" Al-Añam, 6: 119

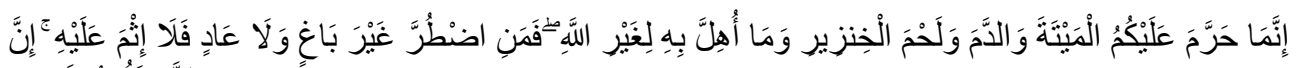

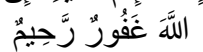

"He has only forbidden you dead meat, and blood, and the flesh of swine and that on which any other name has been invoked besides that of Allah. But if one is forced by necessity, without wilful disobedience, nor transgressing, due limits-then is he guiltless. For is Allah Off Forgiving Most Merciful" (Al Baqarah, 2:173)

$$
\text { 先... }
$$

"..But if any is forced by hunger, with no inclination to transgression, Allah is indeed Oft-Forgiving Most Merciful"

Even though the writers have agreed on the general rule of necessity that permits the usage of prohibited materials, they are not in consensus on the interpretation of darurat and the usage of the prohibited material during necessity. Relating this to the usage of the COVID-19 vaccine during the spread of the fatal virus, it can be said that humans bear a huge duty when it comes to health, for which they will be held accountable to God on the Day of Judgment. Vaccination is thus required because it respects the ideals of the sanctity of human life and the prevention of harm (mafsadah), such as death from the virulent coronavirus's effects.

\section{The Terminology and Concept of Vaccine}

Pharmaceutical and Halal are two words that must be defined separately. The merging of these two words will be made at the end of this subheading with the aim to enlighten the meaning undertaken within this study.

The origin of the word pharmaceutical derives from the Greek Latin word pharmaceuticus, or pharmakeuein, which means to administer drugs (Merriam-Webster Dictionary, 2012). This was later developed by many other usages of the word pharmaceutical, which can be divided into persons involved in the pharmaceutical industry and pharmaceutical as a medication product. As an adjective, it carries the meaning of anyone engaged in pharmacy or the manufacture and sale of pharmaceuticals.

However, the usage under the context of a noun would highlight the word pharmaceutical as a consumable product which is interpreted as any substance used in the treatment of disease which is inclusive of drug, medicament, medication, or medicine (Education Yahoo, 2012). Its synonyms 
include the words cure, drug, medicament, physic, and remedy. Under the legal dictionary (LegalDictionary, 2012), these itineraries are extended to include alterant, anaesthetic agent, antibiotic, chemical substance, curative preparation, and medical component.

There is also the definition that uses the word pharmaceutical as a noun but has inserts the definition to include the place of preparation. This definition states that the drugs or medicine is the one prepared or dispensed in pharmacies (Mayer Brown, 2009). Analogically, some do interpret this word by the process involved in its production. This interpretation states that pharmaceutical is as of or pertaining to the knowledge or art of pharmacy or to the art of preparing medicines according to the rules or formulas of pharmacy (Webster-Dictionary, 2012). The Encyclopaedia Britannica (2012) has extended this word to highlights the functions of pharmaceutical products, where it explains that pharmaceutical is any substances used in the diagnosis, treatment or prevention of disease and for restoring, correcting or modifying organics functions.

This definition method is in line with the definition given by the medical glossary (2012). The medical glossary defines pharmaceutical as any drugs intended for human or veterinary use, presented in their finished dosage form. Included here are materials used in the preparation and formulation of the finished dosage form. It was further elaborated that pharmaceuticals are generally classified by chemical group according to the way they operate in one body which is dependent on the pharmacological effect. They are sometimes categorised following their therapeutic use. For example, pharmaceuticals that are made from natural substances are known as alkaloids, e.g. quinine, nicotine, cocaine, morphine. While those derive from the animal are known as insulin and hormones.

\section{The Urgent Demand for Covid 19 Vaccine}

Malaysian Prime Minister encourages the food industries in Malaysia to be strictly halal compliant so as to penetrate the global food market (Nurulhuda Noordin et al., 2009). Along this decade, the focus has expanded to more than the halal food industry. The government has concentrated on several main areas which will be focusing on halal development. By January 2012, eleven guidelines had been created to assist and govern the Halal industry as a whole which is inclusive of the MS 2424: 2012 Halal Pharmaceuticals - General Guidelines. On January 30, 2013, Malaysia had marked another milestone when it became the first in the world to accord halal certification for the pharmaceutical product in accordance with the Halal Pharmaceuticals- General Guidelines (Halal Malaysia Portal, 2013).

An individual is protected against the virus when the immune system response to the antigens, which accordingly produces antibodies that fight antigen. This process happens when an individual is vaccinated, where a debilitated, killed or toxoid extracted from bacteria is injected into the body of that individual. Along with this, a group of memory cells is also produced, which results in a faster response if they are exposed to the same antigen. Hence, it can be concluded that the vaccine is the device in precautionary medicine. Another concern that influences the hesitancy among the public is the halal status of the ingredients in the vaccine. This is due to the fact that Muslims are the majority of the population. (Wan Rohani et al., 2017)

In Malaysia, a process of the long-term safety effect of the vaccine is observed. Furthermore, before the license is given, all vaccine is used by the Ministry of Health is required to be registered under Drug Control Authority (DCA). It is important to highlight that before the vaccine can be registered, it must go through three-phase clinical trials to guarantee its safety. Phase 1 of clinical trials is conducted to assess the immune response elicited by a vaccine to confirm the vaccine's safety, followed by phase 2 , where hundreds of volunteers have a history of diseased-acquired group and control group.

Finally, phase 3 which aims to calculate the potency and safety of the vaccine among tens of thousands and to observe the unwanted effect of the vaccine. Ultimately, the vaccine produced is safe to be used as it has gone through a strict process of screening before a license can be granted. 
The year 2011 has marked the conspicuous development of the halal pharmaceutical industry when the government has introduced the MS2424: 2010(p): Halal Pharmaceutical: General Guidelines to better monitor the halal pharmaceutical production within the industry. The new guideline was established on 2 March 2011 (Halal Media Admin, 2011). In support of the guideline, the government of Malaysia has appointed two Compliance Monitoring Authorities within the Pharmaceutical Industry, which are the National Pharmaceutical Control Bureau (NPCB) and the Department of Standards Malaysia. The emergence of this specific guideline has shed some light on the halal pharmaceutical industry.

The development shows that, as important as the halal food industry, the halal pharmaceutical industry has become a commodity that contributes to Malaysian economic growth. The halal labelling to the pharmaceutical product has been said (Bernama, 2012) to have added value to the product. The 2010 global market growth for pharmaceuticals expanded 4\% from 2009 to a value that exceeded USD 820 billion (CCM Press Release, 2011). Thus, export opportunities could well be considered a potential revenue-earning sector.

In responding to the government's vision, many of the important players, which consist of people in the industry, policymakers, related agency and consumer organisations, have positively embarked into activities to promote the expansion of the halal industry. For example, Halal Industry Development Corporation (HDC), as the central implementation agency, has undertaken various activities to uphold the development of the Halal Industry. The Halal Industry Partners Programme (HIPP) was established by HDC to foster the involvement of companies and related associations in promoting halal industry activities. A satisfying effort was made by HDC in 2011, when they published a comprehensive halal reference known as the Halal Index.

Concurrently, the Chemical Company of Malaysia Berhad (CCM) has pioneered the halal pharmaceutical manufacturing industry. CCM is also the authorised body to analyse the evidence from the case of abuse of Halal certification. In 2011 CCM was reported to have made a commendable attempt to export the halal generic medicine. Several literatures such as Jasni, Wan Maseni and Eyas acknowledge that halal has penetrated the pharmaceutical industry worldwide. With these rapid activities being carried out within the developing halal pharmaceutical industry, there is an urgent need to strengthen the legal framework.

\section{The Discoveries of Non-Halal Vaccine Product}

The issue of Halal products has invites debates in various aspects of our lives. These days pharmaceutical product is associated with debates on the hazardous effects resulting from the consumption of the products, the insertion of the debated ingredients of Genetically Modified Organism (GMO) within the production process, and the undisclosed non-halal ingredients. All of these issues are within the prohibition under the true concept of 'Halalan Toyibban'. Halal and haram are universal terms that apply to all facets of life. Halal supply chain involves the entire circle of production, distribution, and marketing processes by which consumer receive their requested product (Suhaiza Zailani et al., 2010).

Recent development shows the diversion of demand towards halal pharmaceutical certification. The demand of the society was ignited by the variously reported discoveries from 2006 to 2011, where there have been cases on the non-halal content used in pharmaceutical products. Among the complaints (Mohd Amri, 2011) is on the famously used drug, known as clexane and fraxipane, which is said to have contained porcine. Porcine is a scientific name for pork. They are usually used in medication production or the process of biotechnology. These drugs are usually used by doctors to dilute the blood for patients suffering from irregular heartbeats and during operation.

Abdul Rahman, in his book (Abdul Rahman, 2012), quoted an email that was sent to JAKIM in 2006 to complain about this matter. JAKIM confirms that as of that date, JAKIM's halal certification did not extend to pharmaceutical products. In the same year, there was also the discovery of porcine in another pharmaceutical product scientifically known as Drixoral, which is used to treat influenza. Later in 2008, pilgrimage candidates were taken aback by the fact that the vaccine injection, $A C Y W$ 
135- Menomune, that they received to prevent the meningococcal meningitis disease, was reported to have contained amino acid deriving from duck, swine, and bovine. The revelation continues, where in 2010, Imodium Capsule to treat diarrhoea was said to have contained the same non-halal substance. This has resulted in an immediate call off to its license by the Ministry of Health (Ikhwan Ideris, 2012).

News published by The Star on the $2^{\text {nd }}$ of March 2021, entitled "New vaccine shows promise", informed the readers that recent studies from the United Kingdom suggested a single dose of the Pfizer vaccine can provide strong protection against Covid-19. Research by Juan (2021) shows that the Covid-19 vaccine, such as the Pfizer-BioNTech, is made up of safe, efficacious, and free from any impermissible ingredients in preventing symptomatic Covid-19 disease, including the messenger ribonucleic acid (mRNA) molecules, lipids, salts, and sugar, and thus can minimise the vaccination refusal among the Muslim societies that argue about the halal status of Covid-19 vaccines.

\section{The Force of Elucidating the Dire Discoveries}

In responding to these worrying phenomena of the non-halal pharmaceutical product, the National Fatwa Council has stepped in to decide on the religious standing of the debatable pharmaceutical product. Fatwa is a collection of decisions or legal opinions made together by the Mufti's appointed as the members of the National Fatwa Council. Refer to section 34 of the Administration of Islamic Law (Federal Territories) Act 1993. There are various decisions made by this Council relating to halal pharmaceutical, i.e. the 94, 81, 73, 53 meetings of the National Fatwa Council. The making of religious rulings by the National Fatwa Council on halal pharmaceutical ingredients is an indication that significant focus is now directed to the halal pharmaceutical industry. However, fatwa is not binding unless it is inserted in the State Islamic Laws, in which the jurisdiction will be confined to the State.

\section{Dharurah: The Rule of Necessity}

Darurah in the Arabic language is derived from darar, which means an injury that cannot be avoided (Saim Kayadibi, Istihsan, 2010). Abdur Rashid extends the definition of darar to mean to harm, impair, damage, or hurt, which is the opposite of benefit (Mansour Z. Al-Mutairi, 1997). Several writers (Harmy Mohd Yusoff et al., 2011) who have researched and written on halal and haram acknowledged that necessity would lift the prohibition to use and consume haram goods; thus necessity permits prohibited things. However, it can be seen that the Islamic jurists are divided in agreeing on whether non-halal medicine is allowed to be taken in cases of necessity. Eminent Muslim scholars, like Yusuf al-Qaradawi states that some jurists do not consider non-halal medicine to be necessary for any emergency. He further states that these jurists cited the following Hadith to support their argument.

The Prophet Muhammad S.A.W. says,

"Allah has not made things that are unlawful for you to consume to be your medicine." (al-Bayhaqi)

On the other hand, other jurists maintain that in cases of emergency, the rule on non-halal is lifted. They based their argument on the ground that both food and medicine preserve man's life. These jurists support their argument with the hadith of Prophet Muhammad S.A.W. narrated through Anas r.a. They said that although male Muslims are not allowed to wear silk garments, the Prophet Muhammad S.A.W. has allowed both ${ }^{\circ} A b d u l$ al-Rahman ibn'Awf and al-Zubayir ibn al-AAwwam to wear it because of necessity. The two men were suffering from allergies.

In the book Durar al-Ahkam, dharurat is a situation that forces a person to perform an act that is prohibited by sharia (Ali Haidar, 1996). When there is an excessive need or difficulty, and no one can withstand it, the concept of dharurah can be applied. However, dharurah should not be used arbitrarily, 
especially in determining an action or transaction that is clearly illegal for one's own benefit. Islam is for convenience, never for hardship (The Prophet Muhammad S.A.W. as recorded in Bukhari, Tirmidthi, Abu Daud). In daily life, there are times when unexpected things and emergencies occur; hence avoiding things that are forbidden becomes very difficult.

There is a narration from Anas radhiyallahu 'anhu who mentions that Rasulullah shalallahu'alaihi wasallam gave relief (rukhsah) to Zubair bin Al-'Awwam and Abdurrahman bin Auf to wear silk cloth to treat his skin diseases. However, the relief given for treatment purposes with forbidden means is not absolute and subject to certain conditions.

Rasulullah S.A.W. also once said which means:

"Indeed, Allah does not send down disease, unless He also sends down its cure (Abdul Aziz 1999; al-Bukhari 2003)

As Muslim consumers, the issues related to the halal and haram of medicine are very much emphasised so that we get the quality of hygiene as prescribed by Allah S.W.T. Nevertheless, it is undeniable that the current Muslim community has lack experts in the field of pharmaceuticals, and it is being pioneered by non-Muslims. Medicines are inseparable from general human use, where the source of medicine used consists of several groups of materials, namely human, animal, plant, soil, and water resources. Nevertheless, through modern technology, most medicine today use synthetic substances that are closely related to alcohol, gelatine, and drugs (Department of Islamic Development Malaysia, 2004).

Among the forbidden substances in the pharmaceutical field are such as gelatine, alcohol, and drugs. Gelatin is used in the manufacture of hard capsules, soft capsules, tablets, replacement serums and injections. The $8^{\text {th }}$ Muzakarah of the Fatwa Committee of the National Council for Islamic Religious Affairs of Malaysia, which convened on 24-25 September 1984 has decided that the use of gelatine in medicine at present is required due to emergency.

Meanwhile, no doubt that alcohol consumption can cause damage to organs such as the liver and cause cancer. While methanol has a more harmful effect that can cause blindness and death. Prof. Dr. Yusuf al-Qaradhawi (2017) states that alcohol resulting from processes other than fermentation is sacred. The Malaysian National Fatwa Council also voted for the opinion that alcohol produced according to this process is not unclean. The stand was taken by the Fatwa Lajnah al-Azhar and the Fatwa Lajnah Daimah Saudi.

Like alcohol, drugs are intoxicating, delusional and can cause addiction to the user. However, the benefits of drugs in the medical world are undeniable. Opium, for example, is used in medicine as a painkiller to relieve severe pain, cancer, and labour pains. Examples of commonly used drugs are morphine and pethidine, as well as codeine (cough medicine). Cannabis was once used as a painkiller, while cocaine was used to anaesthetize and stop bleeding (Bahagian Kawalan Penyakit, 2013).

It can be summarised that the rule of necessity is only applicable where the following can be ascertained. Firstly, there is a real and actual necessity. In order words, there is no alternative to stop the emergency. Secondly, the consumption of non-halal food or drugs must be proportionate only to discard the emergency. The diminishing of emergency will disqualify the Muslim to continue consuming non-halal drugs or food. Thirdly, in receiving treatment or medication advice, the adviser (doctor) must be a Muslim who has knowledge in the medical and religious fields.

\section{NPRA in Monitoring Halal Vaccine}

In October 1978, the government under the Ministry of Health had set up the National Pharmaceutical Control Laboratory, which was to carry out the quality control activity of the Pharmacy and Supply Programme (NPCB, 2013). The task was later extended in 1985 when this unit by its new name, National Pharmaceutical Control Bureau (NPCB), was given the sole authority to ensure the quality, 
efficacy, and safety of pharmaceuticals through the registration and licensing scheme. Their jurisdiction covers medicinal products and cosmetics.

Under the ASEAN Technical Co-operation among Developing Countries (Asean TCDC) Program, NPCB has been chosen and recognised by the ASEAN countries as the regional training centre for quality control of pharmaceuticals (NPCB, 2012). In accomplishing this task, NPCB has been receiving trainees from ASEAN and other countries, including Myanmar, Bangladesh, Vietnam, Pakistan, Philippines, Indonesia, India, Sri Lanka, Thailand, Macao, Singapore, Hong Kong, Laos, Cambodia, and Mongolia. This has position Malaysia to be the global training centre for pharmaceutical governance.

Simultaneously, NPCB officers have been sent to Sri Lanka, Mongolia, and Vietnam as consultants. In view of the technical expertise and training capabilities of NPCB, it received recognition as a "WHO Collaborating Centre in the Regulatory Control of Pharmaceuticals" on 10 May 1996 (BPFK, 2012). The designation of NPCB as a WHO Collaborating Centre for regulatory Control of Pharmaceutical is effective for a new period of 4 years from 1st August 2011.

It can be seen that NPCB plays an important role at the local and international levels in safeguarding the pharmaceutical industry. In contrast, its role in assisting in promoting halal pharmaceuticals can't be seen on paper; thus, there is an undeniable implied contribution. The Halal matters are governed within the jurisdiction of JAKIM and the Ministry of Domestic Trade, Cooperation and Consumer Affairs as provided under the Trade Description Act 2011 (Section 28 and 29). This Act is to be read together with its subsidiary regulation, namely the Trade Description (Definition of Halal) Order 2011, The Trade Description (Certification and Marking of Halal) Order 2011 and the Trade Description (Certification and Marking of Halal Fee) Order 2011. Other relevant statutes that can be referred to is the State Criminal Shariah Enactments, Consumer Protection Act 1999 and Sale of Drugs Act 1952, the Medicines (Advertisement and Sale) Act 1956, Sale of Food and Drugs Ordinance 1952 and the Control of Drugs and Cosmetics Regulation 1984. The statutes are scattered, which usually leads to ineffective enforcement due to uncertain power and authority.

The principle of safety, quality and efficacy are in line with the halal concept of 'thoyibban' or wholesome. This means that NPCB has been safeguarding the Islamic dietary principle when they are entrusted to ensure the wholesome concept within the pharmaceutical industry. Nonetheless, the Islamic dietary principle requires the need to consume Halal and thoyibban. It is within this combination that the role of NPCB is viewed as incomplete. Safety, efficacy, and quality does not guarantee that the pharmaceutical products are halal. Being the main regulatory authority within the pharmaceutical industry, NPCB holds a vital position to help in promoting and governing halal pharmaceuticals.

Halal Corporation Development (HDC) is working together with Chemical Company of Malaysia (CCM) and Standards Malaysia on the development of Malaysian Standard for Halal Pharmaceutical: MS2424: 2010. This guideline works together with the Good Manufacturing Practice (GMP) and Pharmaceutical Inspection Co-operation Scheme (PIC/S), which strictly regulate and monitor the sector. The role of HDC seems to be conspicuous in promoting halal pharmaceuticals. This is in concordance with the underlying reason for the establishment of HDC as a sole agency to carry out halal related activities. In the development of Halal pharmaceutical, HDC is working alongside JAKIM and CCM. While NPCB, which is a creature of the Ministry of Health, plays a significant supporting role.

It can be seen that the monitoring of the pharmaceutical industry became the main consideration in the structuring of the NPCB department. NPCB is divided into seven main centres, which are Centre for Product registration, centre for Post Registration of products, Centre for Investigational New Product, Centre for Compliance and Licensing, Centre Organisational Development, Quality Control Department, and the Administration Centre (Halal Media, 2011). 
Currently, Halal monitoring was not delegated under any of the existing centres. In Halal pharmaceutical, the relevant authorities are JAKIM as the governance of Halal, aided by the Ministry of Domestic Trade, Co-operatives and Consumerism and the State Islamic Authority Council (The Trade Description (Certification and Marking of Halal) Order 2011). In comparison, NPCBs' jurisdiction is confined to the pharmaceutical industry. NPCB's position as the regulatory body for the pharmaceutical industry will be in the most suitable position to safeguard the halal pharmaceutical industry. Thus, the development of halal pharmaceuticals, the legal framework requires NPCB to be given a bigger role in the industry.

\section{JAKIM in Monitoring Halal Vaccine}

Starting from the introduction of MS1500:2004, JAKIM has been authorized to be the reference centre and distinguished certification body. In addition, JAKIM was also authorized to certify the raw material and semi-finished product from a foreign country. Currently, there is no specific Halal guidelines for the vaccine but MS2424: 2012 General Guidelines for Halal Pharmaceutical includes vaccine. Some studies (Zainaba C. P Veeravu, 2010) commented that currently, there is inadequate number of officials undertaking the enforcement and monitoring activities. The worrying scenario has led to the creation of an improvised halal logo with the increase on the logo safety, which aims at preventing its abuse. Consequently, with the collaboration between the DSM and JAKIM, the MS1500:2009 was formulated (MS 1500:2009) with an audit system that is in line with the international standard (ISO/IEC Guide 65). Before the introduction of MS2424:2012: General Guidelines for Halal Pharmaceutical, halal pharmaceuticals had been governed by this guideline.

In relation to halal related matters, JAKIM becomes the main agency entrusted by the government to govern halal certification. Certification gives assurance to the consumer that the halal-certified product is indeed halal. Thus, certification is subject to the laws and administrative regulation that ensures that the parties who received certification comply with the halal regulations. Monitoring and auditing are the mechanisms used as the administrative regulation to ensure compliance with the halal pharmaceutical guidelines for pre-certification and post certification. Thus, the governing of halal vaccine is the same as the governing of other halal industry.

The responsibility of granting Halal certification in Malaysia is solely lies in the hands of JAKIM (Zaina et al., 2015). Generally, before a medicinal product can be marketed, it must first get an approval from Drug Control Authority (DCA), namely National Pharmaceutical Regulatory Agency (NPRA). The product will be inspected for quality, safety and potency based on Drug Registration Guidance Document (DRGD), 2nd Edition, September 2016 as published by the Director of Pharmaceutical Services under Regulation 29, Control of Drugs and Cosmetics Regulations 1984 (Ministry of Health (MOH), 2019).

Next, the product will be audited by JAKIM through a Halal Pharmaceutical Audit, which is based on MS 2424:2012 standard. The product evaluation will consider opinion given by National Pharmaceutical Regulatory Agency (NPRA) regarding its production process and formulation. Halal certification can be granted once all this process was completed and succeeded (Jabatan Kemajuan Islam Malaysia (JAKIM), 2014).

\section{The Role and Relevance of IFANCA and HFCE Certification}

Halal products also have a huge demand from countries that are not Muslim-dominant, especially among major exporting countries such as United States of America, Europe, and Australia (Latif, et al., 2014). Accordingly, this triggered these countries to come up with their own halal certification bodies, including Islamic Food and Nutrition Council of America (IFANCA) and Halal Food Council of Europe (HFCE) which provide third-party halal certification. This effort has favourably affected the health-conscious non-Muslim communities. (Islamic Food and Nutrition Council of America, 2017; Halal Food Council of Europe, 2017) 
Halal certification in Malaysia for import products are certified by agencies recognised by JAKIM. This simply means they are no longer required to be certified by JAKIM before being put in the market. However, by virtue of the ruling prescribed in MS 2424:2012, this ruling is not applicable to vaccines. (Department of Standards Malaysia, 2012).

\section{Fatwa}

Fatwa (The Administration of Islamic Law (Federal Territories) Act 1993 (Act 505)) is considered as part of the source of law for halal pharmaceutical product. All enforcement activities and prosecution of case on the false labelling of halal pharmaceutical product depends on the rulings made by the National Fatwa Council (Fatwa Committee of the National Council for Islamic Religious Affairs Malaysia, 1997).

In Malaysia, fatwa can be made by two authoritative councils which are the National Fatwa Council and the State Fatwa Council. The former is applied throughout Malaysia, while the latter is confined within the state boundary. Fatwa does not become binding unless it is inserted in the State Shari'ah Enactments (Baig, A. A, 2009). The Office of the Mufti of the Federal Territories (PMWP) has agreed to adopt the resolution of the Muzakarah (discussion) of the Fatwa Committee of the National Council for Islamic Religious Affairs on the 3rd of December, 2020, as reported by Bernama (2021) in the New Straits Times on the 14th of February, 2021 where the meeting has decided that the usage of COVID-19 vaccine is permissible and compulsory for groups which have been identified by the government. Unquestionably, this resolution is in line with the preservation of life in the objectives of Shariah.

Mufti of the Federal Territories, Sahibus Samahah Datuk Dr. Luqman Abdullah said from the perspective of consumerism, only vaccines that have been identified as halal and tayyiban will be used for the National Covid-19 Immunisation programme (Bernama, 2021).

\section{Conclusion and future Recommendation}

In summary it can be said that, in supporting the wishes of the government to become a halal hub country there is a need to get the world recognition to the governance system within the halal industry. Halal pharmaceutical industry has become a vital part to this role. Preparing a good monitoring system for a reliable halal pharmaceutical would aid this attempt.

NPCB are currently uncertain on its role to govern halal pharmaceutical industry. It is recommended that the existing division within NPCB be extended to include a specific department of halal drugs. Extension would always involve increased of cost. To elucidate this matter, may be its time to consider that NPCB be given the power to certified halal pharmaceutical product so as to allow minimum fees be charged to the applicants. This recommendation would be effective when the officers assign to this halal drugs department are consisted of officers certified with the knowledge of halal and pharmaceutical. With many institutions currently offers a Halal Diploma in various field, there would be the possibility of making this a reality.

It would be another suggestion to create a consultant-based services, whereby the pharmaceutical company who are interested to certified halal its product, could employ the services of NPCB's officer for a fixed period to certify and monitor the ongoing production. These NPCB's officer must be the one assign to the halal department as proposed above. This may be the area that can be research on in future. 


\section{Acknowledgment}

The authors hereby wish to thank officers of NPRA for their kind assistance and endless support during the interview. Our thanks are also extended to the direct and implied related authors whom their writings have contributed to the data gathered in this research.

\section{References}

Abd Latif I, Mohamed Z, Sharifuddin J, Abdullah AM, Ismail MM. (2014). A comparative analysis of global halal certification requirements. J Food Prod Mark, 20(1), 85-101. doi:10.1080/10454446.2014.921869

Abd Rahman. (2012). Halalkah Ubat Anda? Panduan Penting Untuk Umat Islam. Selangor: Crescent News (K.L) Sdn. Bhd.

Abdul Rahman. (2012). Halalkah Ubat Anda? Panduan Penting Untuk Umat Islam. Kuala Lumpur: Cresent News

Abdur Rashid Siddiqui. (2010). Qur'anic keywords: a reference guide. UK: The Islamic Foundation, 70-71

Al Baqarah, 2:173.

Al-Añam, $6: 119$.

Aznan Hasan. (2012). Shariah Principles in Halal Products., Shariah Law Reports(ShLR).

Baig, A. A. (2009). Drinking Intoxicating Liquor or Alcohol: The Shariah Punishment and with Reference to the of Kartika Sari Dewi Shukarno. Shariah Law Report, 1-10

Baran, T. (2020). A literature review and classification of the studies on"halal"in Islamic businessjournals (2010-2018). Journal of Islamic Marketing.

Bernama. (2021). FT Mufti: Covid-19 Vaccine Permissible for Muslims. New Straits Times. Retrieved from https://www.nst.com.my/news/nation/2021/02/665673/ft-mufti-covid-19vaccine-permissible-muslims.

Biro Pengawalan Farmaseutikal Kebangsaan (BPFK). (2012). Kementerian Kesihatan Malaysia.(2012). Retrieved on July 12, 2012 from http://www. Portal bpfk.gov.my/in dex.cfm?\&memid=66

Department of Islamic Development Malaysia. (2014). Joint Guidelines on Control of Medicines In Islam, Putrajaya: JAKIM, http://www.islam.gov.my/en/joint-guidelines-control-medicinesislam (akses November 29, 2014)

Department of Standards Malaysia. (2012). MS 2424: Halal Pharmaceuticals - General guidelines. Malaysian Standard, 2424, 20.

Education Thesaurus.Retrieved on September 16, 2012 from education.yahoo.com/reference/thesauraus/entry/pharmaceutical

Global Pathfinder Report. (2011) Halal Food Trends. Retrieved April 20, 2011 from http://www.gov.mb.ca/agriculture/statistics/.../halal market pathfinder en

H. Ahmad \& Borham J. (2010). Programme Development of a Degree in Halal Administration: Experience in Curriculum Design in Universiti Malaysia Pahang (UMP). International Conference of Education, Research and Innovation. Retrieved on 11 April 2011) from umpir.ump.edu.my/1192/1/FINAL PAPER ICERI2010.

H. Zainuddin Hamidy et al. (2002). al-Imam al-Bukhari, Sahih Bukhari Singapore: Darel Fajr Publishing House.

H.M Hasballah Thaib. (2004). Kapita Selekta Hukum Islam. Medan, Pustaka Bangsa Press.

Halal Food Council of Europe (HFCE) (2017). Frequently asked questions. 2017. http://www.hfce.eu/index.html.

Halal Malaysia Portal. ( 2013). Malaysia Negara Pertama Menganugerah Pensijilan Halal Berdasarkan Standard Farmaseutikal Halal Terulung di Dunia. Retrieved on Februari 2, 2013 from http://halal.gov.my/v3

Halal Media Admin. (2011). Malaysia introduces New Halal Pharmaceuticals Standard. Retrieved on August 8, 2011 from http://halalmedia.my/malaysia

Harmy Mohd Yusoff et al. (2011). Fikah Perubatan. Selangor: PTS Millenia Sdn. Bhd. House of Publishers Sdn. Bhd. 
Ikhwan Ideris. (2010). Ubat Gelatin Babi Ditarik Balik. Kosmo Online. www.kosmo.com.my

Islamic Food and Nutrition Council of America (IFANCA) (2017). Frequently asked questions. http://www.ifanca.org/Pages/Index.aspx.

ISO/IEC Guide 65

Jabatan Kemajuan Islam Malaysia (JAKIM). (2014). Manual Procedure for Malaysia Halal Certification (Third Revision) 2014. Jabatan Kemajuan Islam Malaysia (Jakim), 67. http://www.halal.gov.my/v4/images/pdf/MPPHM2014BI.pdf

Jabatan Mufti Kerajaan (2007). Fatwa Mufti Kerajaan: Isu-Isu Produk Halal. Selangor: Al-Hidayah

Jamaludin, M. A. \& Ramli, S. N. H. (2021). Covid-19 pandemic: Preservation of Life in Tandem with Shariah Compliances Regarding Covid-19 Vaccines. J Halal Ind Serv., 4(1): a0000201. https://doi.org/10.36877/jhis.a0000201

Jeff Diamant. (2019). The countries with the 10 largest Christian populations and the 10 largest Muslim populations. Retrieved May 29, 2021, from https://www.pewresearch.org/facttank/2019/04/01/the-countries-with-the-10-largest-christian-populations-and-the-10-largestmuslim-populations/

Johan Fischer. (2005). Feeding Secularism: Consuming Halal Among the Malays in London Diaspora. Journal of Transnational Studies, 4(2/3), 275-297

Johan Fischer. (2008). Proper Islamic Consumption, Shopping among the Malays in Modern Malaysia, NIAS Press.

Johan Fischer. (2008). Proper Islamic Consumption, Shopping among the Malays in Modern Malaysia. Denmark: Nia Press

Legal Dictionary. Retrieved on September 16, 2012 from www.legal-dictionary.the freedictionary.com/phamaceuticals

Leonard Ariff Abdul Shattar. (2011). The Perspective and Requirement of the Halal Pharmaceuticals Logistic Providers' from the Industry Point of View. Halal Logistic Seminar, Kuala Lumpur

Macmillan Dictionary. Retrieved on September 20, 2012 from www.macmillandictionary.com/dictionary/americaphamaceutical

Make Malaysia as a Bench Mark. Retrieved on August 24, 2007 from http://www.HalalJournal.com.doc. page=article\&act=show

Mansour Z. Al-Mutairi. (1997). Necessity in Islamic Law. (Ph.D thesis, University of Edinburgh, UK.

Mayer Brown. (2009). Product Market Definition in the Pharmaceutical Sector: The effect of a Recent Focus on Generics. Martindale. Retrieved on 3 October 2012, Lexis-Nexis via UiTM online subscription

Medical Glossary. Retrieved on September 16, 2012 from www.medicalglossary.org/chemicals_and_drugs-pharmaceutical-preparation-definition.html

Merriam- Webster Dictionary. Retrieved on September 16, 2012 from http:www/merriamwebster.com/dictionary/pharmaceutical.

Mian N. Riaz \& Joe. M. Regenstein. (2011). Nutritional supplements for Halal and Kosher Consumers: Religious based Dietary Laws impact ingredient options for supplement manufacturers. Retrieved August 8, 2011 http://findarticles.com

Mian N. Riaz and Muhammad M Chaudry. (2004). Halal Food Production. USA:CRC Press.

Mian N. Riaz et al. (2003). Halal Food Production. Taylor \& Francis.

Micheal Keene. (1999). This is- Islam New Revised Edition. UK: Stanley Thornes. Retrieved on July 20, 2011_http://www.books.google.com

Ministry of Health (MOH). (2019). Drug Registration Guidance Document (DRGD) National Pharmaceutical Regulatory Division. National Pharmaceutical Regulatory Division, Second edi, 113-133. https://www.npra.gov.my/

Mohd Amri Abdullah. (2011). Saintis Muslim Bertanggungjawab Bangunkan Sumber Halal Kapsul Gelatin. Berita Harian

Mohd Cholil Nafis. (2020). The Concept Of Halal And Thayyib And Its Implementation In Indonesia. Journal of Halal Product and Research, 2(1).

News Press release. (2021). Global Halal Market Analysis 2021 with Top Countries Data Industry Price Trend, Size Estimation, Industry Outlook, Business Growth, Report Latest Research, Business Analysis and Forecast Analysis Research | With Covid 19 Analysis" https://www.ktvn.com/story/43330930/global-halal-market-analysis-2021-with-top-countriesdata-industry-price-trend-size-estimation-industry-outlook-business-growth-report-latest 
Niche Position an Industry Advantage for Halal Industry. (2011). CCM Press Release. Retrieved on January 3, 2013 from www.ccmberhad.com/about ccm/halal

Nik Maheran Nik Muhammad, Filzah Md Isa, Bidin Chee Kifli. (2009). Positioning as Halal-Hub: Intergration Role of Supply Chain Strategy and Halal Assurance System. Asian Social Science Journal, 5(7).

Noraine Hamzah (2010). Pemantauan dan Penguatkuasaan Halal di Malaysia. PhD thesis.UKM.

Norazlina Abdul Aziz. (2007). The Compliance of Biotechnological Product to the Halal Requirement. Paper presented at the $4^{\text {th }}$ ASLI Conference organized by ASLI and Universitas of Indonesia, Jakarta.

Noreen Noor Abd Aziz, Nurul Eien Abd Aziz, Nurul Ashyikin Abd Aziz, Zurina Omar, Wan Haslin Azizh Wan Hassan. (2015). A Review on the Emergence and Growth of Halal Studies. Procedia Economics \& Finance, 31, 325-332.

Nurulhuda Noordin, Nor laila Md Noor, Mardziah Hashim, Zainal Samicho. (2009). Value Chain of Halal Certification System: A Case of the Malaysia Halal Industry. Paper presented at the European Mediterranean Conference on Information Systems organized by Brunel University and Dokuz Eylul University, Turkey

Pazim Othman, Irfan Sungkar, Wan Sabri Wan Hussin. (2009). Malaysia as an Independent Halal Food hub: Competitiveness and Potential of Meat- based Industries. ASEAN Economic Bulletin, volume 26

Rokshana Shirin Asa \& Ida Madieha Abdul Ghani Azmi. (2018). The Concept Of Halal And Halal Food Certification Process In Malaysia: Issues And Concerns. Malaysian Journal Of Consumer And Family Economics, 38-51.

Rosly Othman, Suhaiza Hanim Mohamad Zailani, \& Zainal Ariffin Ahmad. (2007) Production of Halal Food: Practices of Muslim Small Enterprises in Malaysia. Social Sciences Conference Retrieved June 1, 2011 http://i08.cgpublisher.com

Saim Kayadibi (2010). Istihsan: The Doctrine of Juristic Preference in Islamic Law. Kuala Lumpur: Islamic Book trust.

Shaykh Mufti Muhammad ibn Adam. (2011). Using Unlawful (haram) Medication,” Shariah Program Articles Library, Leichester, UK http://www.shariahprogram.ca/eat-halal-foods (accessed on 20 July 2011);

Sijil Halal Bertaraf Global. (2003). Utusan Malaysia, p. 10

Sue Penny. (2006). Islam. Sue penny books.goggle.com

Suhaiza Zailani,Zainal Ariffin, Nabsiah Abd Wahid, Rosly Othman and Yudi Fernando. (July, 2010). Halal Traceability and Tracking Systems in Strenghtening Halal Food Supply Chain for Food Industry in Malaysia: A Review. Journal of Food Technology, 8(3).

Syekh`Abd Shukur Rahimy Mằmur Dawud (2003). Terjemahan Hadith Sahih Muslim, Jilid I,II,III,IV. Singapore:Darel Fajr Publishing House.

The Launching of the First Halal Pharmaceutical Standard in the World. Bernama 1 October, 2012 Retrieved on January 1, 2013 from www.bernama.com.my

The New Encyclopedia Britannica, 15 $5^{\text {th }}$ Edition. Retrieved on September 16, 2012 from www.britannica.com/EBchecked/topic/pharmaceutical

The Webster Dictionary, $7^{\text {th }}$ edition. Retrieved on September 20, 2012 from www.websterdictionary.com

World Population Review. (2021). Muslim Population By Country 2021. Retrieved on May 29, 2021 from https://worldpopulationreview.com/country-rankings/muslim-population-by-country www.e-fatwa.gov.my/fatwa-kebangsaan/gelatin-dalam-ubat

Yasmin Hanani. (2010). Necessity (darura) in Islamic Law: A Study with special reference to Harm Reduction Programme in Malaysia. Ph.D thesis, University of Exeter, UK.

Yusuf Al Qardawi. (2001). The lawful and the Prohibited in Islam. Egypt: Al Falah Printing and Publication.

Yusuf al-Qaradawi (2009). The Lawful and the...., 41; Securities Commission Malaysia, Islamic Commercial Law (Fiqh al-Múamalat). Selangor: LexisNexis Malaysia Sdn Bhd.

Zaina, C. R. C. M., Rahmanb, S. A., Ishanc, Z. M., \& Azizd, S. A. (2015). Jurisdiction and Prosecution of Halal Related Matters in Malaysia: Challenges and Prospects. Procedia - Social and Behavioral Sciences, 172, 294-300. https://doi.org/10.1016/j.sbspro.2015.01.367 
Malaysian Journal of Social Sciences and Humanities (MJSSH), Volume 6, Issue 10, (page 413 - 428), 2021

DOI: https://doi.org/10.47405/mjssh.v6i10.1084

Zainaba C. P Veeravu. (2010). Peranan Jakim dalam Pengesahan Produk Halal dan Kepentingannya kepada Pengguna Islam. Phd Thesis.UKM. 